\title{
Pengetahuan dan Sikap Lansia tentang Penggunaan Obat Tradisional Hipertensi
}

\author{
Awaluddin', Purwanto ${ }^{2}$ \\ ${ }^{1,2}$ Prodi Keperawatan, STIKes Tengku Maharatu, Pekanbaru, Riau, Indonesia \\ awaluddinhasan@yahoo.com
}

\begin{abstract}
The used of traditional medicines to decrease hypertension were increased. The used of them were influenced by knowledge and attitude. The purpose of this study was to known the correlation of knowledge and attitude of the elderly in use of the traditional medicine to reducing hypertension in Batang Tumu Health Center, District of Indragiri Hilir. This study was analytical withcross sectionaldesign. The population were all elderly who had hypertension as many as 143 respondent. The number of samples in this study were 59 respondents. The technique of sampling was purposive. Measuring instrument used was questionnairre. The results showed that elderly with well knowledge were 31 respondents (52.2\%) and positive attitude were 38 respondents (64.4\%). The chi square test results showed that there was a significant correlation between knowledge with the use of traditional medicine to reduce hypertension with $p$ value $0.002<$ alpa 0.05. There was a significant correlation between elderly attitude with the use of traditional medicine to reduce hypertension with $p$ value 0.004 <alpa 0.05. This result of study had implication to nursing that needed good knowledge and positive attitude for elderly so that can be use hypertension traditional medicine.
\end{abstract}

Keywords: hypertension, elderly, traditional medicine, knowledge, attitude

\begin{abstract}
Abstrak
Penggunaan obat tradisional untuk menurunkan hipertensi semakin mengalami peningkatan. Penggunaan tersebut dipengaruhi oleh pengetahuan dan sikap. Penelitian ini bertujuan untuk mengetahui hubungan pengetahuan dan sikap lansia dengan penggunaan obat tradisional untuk menurunkan hipertensi di UPT Puskesmas Batang Tumu Kabupaten Indragiri Hilir. Penelitian ini bersifat analitik dengan menggunakan desain cross sectional. Populasi adalah seluruh lansia yang menderita penyakit hipertensi yang berjumlah 143 orang. Jumlah sampel dalam penelitian ini 59 responden.Teknik pengambilan sampel secara pusposive sampling. Alat ukur yang digunakan adalah kuesioner. Hasil penelitian menunjukkan lansia yang berpengetahuan baik sebanyak 52,2\% dan sikap positif sebanyak $64,4 \%$. Hasil Uji Kai Kuadrat menunjukkan ada hubungan yang bermakna antara pengetahuan dengan penggunaan obat tradisional untuk menurunkan hipertensi dengan $p$ value 0,002 . Ada hubungan yang bermakna antara sikap lansia dengan penggunaan obat tradisional untuk menurunkan hipertensi dengan $\mathrm{p}$ value $0,004<$ alpa 0,05. Implikasi keperawatan dari hasil penelitian ini menunjukan bahwa diperlukan pengetahuan yang baik dan sikap yang positif bagi lansia agar dapat memanfaatkan obat tradisional hipertensi.
\end{abstract}

Kata Kunci: hipertensi, lansia, obat tradisional, pengetahuan, sikap

Jurnal Keperawatan Raflesia, Volume 1 Nomor 1, Mei 2019

ISSN: 2656-6222, DOI 10.33088/jkr.vlil.397

Available online: https://jurnal.poltekkes-kemenkes-bengkulu.ac.id/index.php/jkr 


\section{PENDAHULUAN}

Tekanan darah tinggi atau hipertensi merupakan suatu keadaan dimana seseorang mengalami peningkatan tekanan darah diatas normal baik tekanan sistolik maupun tekanan diastolik. Hipertensi terjadi karena peningkatan tekanan darah di dalam arteri. Terkadang hipertensi merupakan suatu keadaan tanpa gejala. Hipertensi dapat menyebabkan meningkatnya risiko kejadian penyakit gagal jantung, stroke, aneurisma, serangan jantung serta kerusakan ginjal (Sunaryati, 2011).

Tujuh koma lima juta kematian atau 12,8\% dari seluruh angka kematian disebabkan oleh hipertensi. Hal ini menyumbang 57 juta dari disability adjusted life years (DALY) (Aoki et al, 2014). Berdasarkan data pasien hipertensi pada orang dewasa di United Statessekitar 25\% pada tahun 2011-2012 dan di Indonesia sebanyak 25,8\% pada tahun 2013. Kisaran usia pasien hipertensi adalah $5 \%$ berusia $20-39$ tahun, $26 \%$ berusia 40-59 tahun, dan 59,6\% berada pada usia 60 tahun ke atas (Aoki et al, 2014). Dari data tersebut dapat dilihat bahwa mayoritas penderita hipertensi adalah lansia, sehingga kelompok lansia ini perlu untuk mendapatkan perhatian. World Health Organization (WHO, 2012) Representative to Indonesia menemukan 1,5 juta orang di Asia Tenggara meninggal tiap tahun karena hipertensi. Prevalensi hipertensi di Indonesia berada pada urutan ke-tujuh setelah Myanmar, India, Srilanka, Bhutan, Thailand, Neple, dan Maldives. Prevalensi hipertensi diprediksi akan meningkat menjadi 1,6 milyar pada tahun 2025 .
Data Riset Kesehatan Dasar (Riskesdas) tahun 2013 menunjukkan kasus hipertensi di Indonesia sebanyak 25,8\% dari jumlah kasus penyakit kronis, dengan jumlah kasus pada laki-laki 22,8\% dan pada perempuan $28,8 \%$. Enam puluh persen diantaranya berakhir dengan stroke. Satu pertiga diantaranya meninggal dunia, sedangkan sisanya sekitar lima juta menderita kecacatan permanen.

Data Dinas Kesehatan Provinsi Riau (2013) menunjukkan bahwa kasus hipertensi sebanyak 4.182 kasus. Data Profil Kesehatan Inhil tahun (2015), menyatakan bahwa penyakit hipertensi menempatkan urutan kedua yaitu 16.942 kasus. Urutan pertama adalah penyakit ISPA sebanyak 29.897 kasus. Sedangkan di Batang Tumu berdasarkan data UPT Puskesmas (2015), hipertensi menempati urutan ketiga penyakit terbesar setelah ISPA dan febris dengan jumlah kasus sebanyak 2.115 kasus. Berdasarkan data enam bulan terakhir di salah satu desa di wilayah kerja Puskesmas Batang Tumu yaitu Desa Bantayan, warga yang menderita hipertensi sebanyak 375 kasus dan terdiri dari 143 kasus pada lansia.

Tingginya angka kejadian hipertensi dapat dipengaruhi oleh pengetahuan dan sikap seseorang (Zaenurrohmah \&Rachmayanti, 2017). Pengetahuan mengenai hipertensi terutama penyebab hipertensi akan mempengaruhi kejadian hipertensi. Kurangnya pengetahuan dapat berpengaruh pada tindakan yang akan dilakukan karena pengetahuan merupakan salah satu faktor predisposisi untuk berperilaku. Selanjutnya sikap juga akan mempengaruhi kejadian hipertensi. Sikap merupakan respon 
seseorang yang belum dapat dilihat terhadap stimulus atau objek tertentu. Sikap ini dapat dilihat dari pendapat dan emosi seseorang (senang atau tidak senang, setuju atau tidak setuju, baik atau tidak baik dan lain-lain).

Penatalaksanaan hipertensi dapat dilakukan dengan pemberian obat tradisional antara lain bawang putih, buah belimbing manis, mengkudu, daun sirsak dan buah manggis. Berdasarkan hasil wawancara terhadap 10 orang lansia yang menggunakan obat tradisional sebanyak 6 orang dan yang menggunakan obat konvensional sebanyak 4 orang. Berdasarkan fenomena di atas maka dilakukan penelitian dengan tujuan menganalisis hubunganpengetahuan dan sikap lansia dengan penggunaan obat tradisional untuk menurunkan hipertensi di Bantayan wilayah UPT Puskesmas Batang Tumu Kabupeten Inhil.

\section{METODE}

Penelitian ini merupakan penelitian kuantitatif observasional dengan pendekatan cross sectional. Penelitian ini dilakukan pada tanggal 1 s.d. 27 Mei 2018. Populasi pada penelitian ini yaitu seluruh lansia yang menderita penyakit hipertensi yang berjumlah 143 orang di Bantayan yang memenuhi kriteria penelitian. Kriteria inklusi dari penelitian ini yaitu lansia yang menderita hipertensi grade I, lansia yang berusia 45 tahun keatas. Sedangkan kriteria eksklusi dalam penelitian ini adalah lansia yang tidak berdomisili tetap dan lansia yang tidak berada di tempat saat penelitian berlangsung. Sampel pada penelitian ini ditetapkan berdasarkan rumus Slovindengan besar sampel sebanyak 59 orang lansia.Teknik pengambilan sampel yang digunakan adalah purposive sampling.

Alat pengumpulan data dalam penelitian ini adalah lembar kuesioner tentang pengetahuan, sikap dan penggunaan obat tradisional hipertensi. Kuesioner diisi oleh responden. Variabel dalam penelitian ini adalah pengetahuan, sikap dan penggunaan obat tradisional. Pengetahuan adalah pengetahuan lansia tentang penggunaan obat tradisional untuk menurunkan hipertesi. Sikap adalah respon lansia terhadap penggunaan obat tradisional untuk menurunkan hipertensi. Penggunaan obat tradisional adalah penggunaan obat alami dengan bahan yang berasal dari tumbuhan.

Uji validitas dilakukan di Puskesmas Tembilahan Hulu tanggal 12 April 2018 pada 20 responden. Setelah dilakukan uji validitas dari 10 butir soal didapatkan hasil 6 butir soal pengetahuan yang valid yaitu nomor p3, p4, p5, p6, p7, p8 dengan nilai $r$ hitung > $r$ tabel 0,552-0,721 dan yang tidak valid p1, p2, p9, p10 dengan nilai 0,3170,426 . Soal sikap dari 10 butir yang valid 5 butir yaitu soal nomor s3, s4, s5, s6, s7 dengan nilai $\mathrm{r}$ hitung $>\mathrm{r}$ tabel $0,685-0,718$ dan yang tidak valid soal s1, s2, s8, s9, s10 dengan nilai 0,232-0,423. Dari keseluruhan soal pengetahuan dan sikap yang tidak valid dikeluarkan dan tidak diuji kembali karena keseluruhan soal yang valid sudah mewakili dari item-item pertanyaan. Hasil uji reliabilitas kuesioner pada penelitian ini menunjukkan nilai $\mathrm{r}$ alpa $>\mathrm{r}$ tabel yaitu 0,824 untuk variabel pengetahuan dan 0,787 untuk variabel sikap sehingga pertanyaan 
tersebut reliabel. Analisa data dilakukan dengan uji Kai kuadratdengan tingkat kemaknaan $95 \%(\alpha=0,05)$.

\section{HASIL}

Tabel 1. Distribusi Frekuensi Responden Menurut Jenis Kelamin di UPT Puskesmas Batang Tumu Kabupaten Inhil

\begin{tabular}{lcc}
\hline Jenis Kelamin & $\mathrm{f}$ & $\%$ \\
\hline Laki-laki & 28 & 47.5 \\
Perempuan & 31 & 52.5 \\
\hline
\end{tabular}

Berdasarkan tabel 1 menunjukkan bahwa distribusi frekuensi responden berdasarkan jenis kelamin dapat diketahui bahwa mayoritas responden adalah perempuan sebanyak 31 responden $(52,5 \%)$.

Tabel 2. Distribusi Frekuensi Responden Menurut Pendidikan di UPT Puskesmas Batang Tumu Kabupaten Inhil

\begin{tabular}{lcc}
\hline Pendidikan & $\mathrm{f}$ & $\%$ \\
\hline SD & 43 & 72.9 \\
SLTA & 6 & 10.2 \\
SLTP & 10 & 16.9 \\
\hline
\end{tabular}

Berdasarkan tabel 2 menunjukkan bahwa distribusi frekuensi responden berdasarkan tingkat pendidikan dapat diketahui bahwa mayoritas responden berpendidikan SD sebanyak 43 responden (72.9\%).

Tabel 3. Distribusi Frekuensi Pengetahuan Responden di UPT Puskesmas Batang Tumu Kabupaten Inhil

\begin{tabular}{lcc}
\hline Pengetahuan & f & $\%$ \\
\hline Baik & 31 & 52,5 \\
Cukup & 19 & 32,2 \\
Kurang & 9 & 15,3 \\
\hline
\end{tabular}

Pada tabel 3 terlihat bahwa mayoritas responden yang berpengetahuan baik sebanyak 31 responden $(52,5 \%)$ dan minoritas pengetahuan kurang sebanyak 9 responden (15,3\%), sedangkan yang berpengetahuan sedang berjumlah sebanyak 19 orang $(32,2 \%)$.

Tabel 4. Distribusi Frekuensi Sikap Responden di UPT Puskesmas Batang Tumu Kabupeten Inhil

\begin{tabular}{lcc}
\hline Sikap & f & $\%$ \\
\hline Positif & 38 & 64,4 \\
Negatif & 21 & 35,6 \\
\hline
\end{tabular}

Dari tabel 4 dapat diketahui bahwa mayoritas responden yang memiliki sikap positif dengan jumlah 38 responden $(64,4 \%)$ dan minoritas responden yang memiliki sikap negatif sebanyak 21 responden $(35,6 \%)$.

\section{Tabel 5. Distribusi Frekuensi Penggunaan Obat Tradisional Hipertensi Responden di UPT Puskesmas Batang Tumu Kabupeten Inhil}

\begin{tabular}{lcc}
\hline $\begin{array}{l}\text { Penggunaan Obat } \\
\text { Tradisional }\end{array}$ & $\mathrm{f}$ & $\%$ \\
\hline Ya & 37 & 62,7 \\
Tidak & 22 & 37,3 \\
\hline
\end{tabular}

Dari tabel 5 dapat diketahui bahwa mayoritas responden menggunakan obat tradisional hipertensi dengan jumlah 37 responden $(62,7 \%)$ dan minoritas responden tidak menggunakan obat tradisional hipertensi`sebanyak 22 responden (37,3\%). 
Tabel 6. Hubungan Pengetahuan dengan

Penggunaan Obat Tradisional untuk

Menurunkan Hipertensi di UPT Puskesmas Batang Tumu Kabupaten Inhil

\begin{tabular}{lcccccc}
\hline \multicolumn{4}{c}{$\begin{array}{c}\text { Penggunaan Obat Tradisional Untuk } \\
\text { Menurunkan Hipertensi }\end{array}$} & & $\begin{array}{c}\text { P } \\
\text { value }\end{array}$ \\
\hline Pengetahuan & Ya & $(\%)$ & Tidak & $(\%)$ & Total & \\
& & & & & & \\
\hline Baik & 28 & 90.3 & 3 & 9.7 & 31 & \\
Cukup & 8 & 42.1 & 11 & 57.9 & 19 & 0,000 \\
Kurang & 1 & 11.1 & 8 & 88.9 & 9 & \\
\hline
\end{tabular}

Berdasarkan tabel 6 dapat dilihat bahwa dari 31 responden yang berpengetahuan baik, 90,3\% responden diantaranya menggunakan obat tradisional. Dari 19 responden yang memiliki pengetahuan cukup 57,9 \% respondentidak menggunakan obat tradisional. Dari 9 responden yang memiliki pengetahuan kurang 88,9 \% responden tidak menggunakan obat tradisional. Hasil uji statistik didapatkan nilai $p$ value $=0,000$ maka dapat disimpulkan bahwa ada hubungan yang signifikan antara pengetahuan dengan penggunaan obat tradisional untuk menurunkan hipertensi di UPT Puskesmas Batang Tumu Kabupaten Inhil.

Tabel 7. Hubungan Sikap Lansia dengan Penggunaan Obat Tradisional untuk Menurunkan Hipertensi di UPT Puskesmas Batang Tumu Kabupaten Inhil

\begin{tabular}{lllllll}
\hline & \multicolumn{5}{c}{ Penggunaan Obat Tradisional } & $\begin{array}{c}\text { P } \\
\text { Sikap }\end{array}$ \\
\cline { 2 - 7 } & Ya & $(\%)$ & Tidak & $(\%)$ & Total & \\
\hline Positif & 29 & 76.3 & 9 & 23.7 & 38 & 0.004 \\
Negatif & 8 & 38.1 & 13 & 61.9 & 21 & \\
\hline
\end{tabular}

Hasil analisa hubungan sikap lansia dengan penggunaan obat tradisional untuk menurunkan hipertensi di UPT Puskesmas Batang Tumu Kabupaten Inhil diperoleh hasil dari 38 responden yang memiliki sikap positif, 29 responden (76.3\%) menggunakan obat tradisional. Dari 21 responden yang memiliki sikap negatif, 13 responden $(61.9 \%)$ tidak menggunakan obat tradisional. Hasil uji statistik didapatkan hasil nilai $p$ value $0,004<$ alpa (0,05). Maka dapat disimpulkan ada hubungan yang signifikan antara sikap lansia dengan penggunaan obat tradisional untuk menurunkan hipertensi di UPT Puskesmas Batang Tumu Kabupaten Inhil.

\section{PEMBAHASAN}

Berdasarkan hasil penelitian maka peneliti akan membahas tentang hubungan pengetahuan dan sikap lansia dengan penggunaan obat tradisional untuk menurunkan hipertensi di UPT Puskesmas Batang Tumu Kabupaten Inhil.

Berdasarkan hasil penelitian yang dilakukan, diperoleh mayoritas responden yang berpengetahuan baik sebanyak 52,5\%. Berdasarkan data tersebut dapat dilihat sebagian besar responden memiliki pengetahuan baik tentang pengetahuan dan sikap lansia dalam penggunaan obat tradisional untuk menurunkan hipertensi di UPT Puskesmas Batang Tumu Kabupaten Inhil. Penulis menyimpulkan bahwa tidak semua responden berpengetahuan baik ada juga responden yang berpengetahuan kurang, hal ini tergantung bagaimana cara seseorang memiliki pengetahuan dan sikap lansia dalam menggunakan obat tradisional untuk menurunkan hipertensi. 
Berbagai upaya yang dilakukan oleh manusia untuk memperoleh pengetahuan. Upaya serta cara-cara tersebut digunakan dalam memperoleh pengetahuan. Menurut Riswandi (2016) salah satu upaya seseorang mendapatkan pengetahuan yaitu dengan bertanya pada orang yang memiliki otoritas atau dianggap lebih tahu. Selain itu pengalaman juga dapat digunakan untuk mendapatkan pengetahuan. Pengalaman masa lalu dapat menyelesaikan masalah yang dihadapi saatini.

Berdasarkan hasil penelitian yang telah dilakukan, dapat diketahui bahwa mayoritas responden memiliki sikap positif dengan sebanyak $64,4 \%$ responden dan minoritas responden yang memiliki sikap negatif sebanyak 35,6\% responden. Berdasarkan data tersebut dapat dilihat sebagian besar memiliki sikap positif dalam menggunakan obat tradisional untuk menurunkan hipertensi. Peneliti menyimpulkan bahwa tidak semua responden memiliki sikap positif ada juga yang memiliki sikap negatif tergantung bagaimana cara responden menyikapi dan menggunakan obat tradisional untuk menurunkan penyakit hipertensi.

Perubahan dan perkembangan sikap dapat dipengaruhi oleh faktor pembelajaran, proses sosial, informasi, budaya dan pengalaman yang baru didapat (Riswandi, 2016). Sikap juga dibentuk melalui kejadian dan peristiwa yang terjadi secara berulangulang dalam waktu yang lama (Sarwono, 2009).

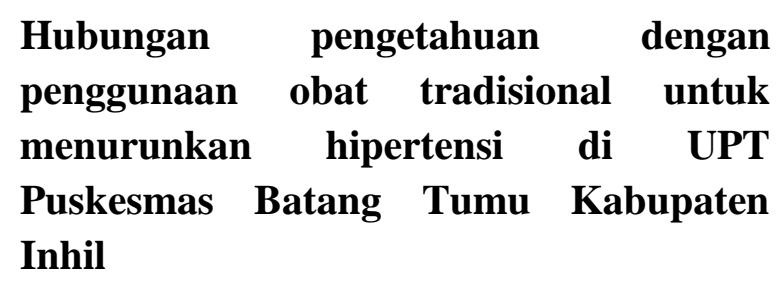

Hasil penelitian menunjukkan bahwa pengetahuan tentang obat tradisional untuk menurunkan hipertensi menyatakan pengetahuan baik sebanyak 31 responden $(52,5 \%)$.Hasil uji statistik didapatkan hasil $p$ value $=0,000 \quad(\mathrm{p}<0,05)$ maka dapat disimpulkan bahwa ada hubungan yang signifikan pengetahuan lansia dalam menggunakan obat tradisional untuk menurunkan hipertensi di UPT Puskesmas Batang Tumu Kabupaten Inhil. Penelitian ini tidak sesuai dengan yang dilakukan Fajri (2013) dengan hasil $p$ value $0.072>(0.05)$ dimana tidak ada hubungan pengetahuan dengan penggunaan obat tradisional untuk menurunkan hipertensi. Penelitian ini berbanding terbalik dengan hasil yang peneliti lakukan dengan nilai $p$ value $0.000<$ (0.05) karena tingkat pendidikan tidak berpengaruh tinggi terhadap masyarakat. Penelitian ini sesuai dengan hasil penelitian (Awaluddin, 2016) bahwa ada hubungan antara pengetahuan dengan tekanan darah pada lansia hipertensi di Balai Pelayanan Sosial Tresna Werdha (BPSTW) Khusnul Khotimah Pekanbaru dengan $\mathrm{p}$ value=0,029. Meskipun penelitian tersebut bukan tentang obat tradisional, tapi dari segi pengetahuan dapat dibandingkan dengan hasil penelitian ini, dimana pengetahuan memiliki hubungan dengan tindakan/suatu kejadian. Hal ini berarti edukasi diperlukan dalam upaya menurunkan tekanan darah pada pasien hipertensi terrmasuk lansia. 
Pengetahuan masyarakat dalam penggunaan obat tradisional juga akan dipengaruhi oleh beberapa faktor. Pemanfaatan obat tradisional pada fasilitas pelayanan kesehatan harus dapat dipertanggungjawabkan. Salah satu diantaranya yang dinilai mempunyai peranan yang sangat penting adalah upaya standarisasi. Standarisasi dibuat untuk meningkatkan kualitas obat tradisional dan menghindari efek samping yang merugikan pasien (Zulkifli, 2007).

Standarisasi digunakan sebagai batas minimal dalam menerima suatu standar dan merupakan keadaan yang ideal atau mempunyai tingkat pencapaian tinggi dan sempurna. Standar tersebut mendekati capaian ideal dan dalam batas yang diperbolehkan (Zulkifli, 2007). Suatu standar dikatakan baik jika memenuhi syarat (1) bersifat jelas yaitu bisa diukur dengan baik dan mengukur kemungkinan terjadinya penyimpangan, (2) logis artinya suatu standar yang masuk akal, yang mencegah frustasinya para profesional, (3) mudah dipahami artinya suatu standar yang baik akan mudah dipahami oleh tenaga pelaksananya, (4) kredibel artinya bisa dipercaya, (5) absah yaitu terdapat korelasi yang kuat dan dapat diartikan antara standar tersebut dengan hal yang mewakilinya, (6) meyakinkan yaitu merupakan perwakilan dari syarat yang ditentukan. Syarat tersebut tidak boleh rendah karena akan mengurangi maknanya, (7) mantap, spesifik, eksplisit yaitu bisa dipengaruhi oleh waktu, memiliki ciri khas dan memiliki keterbukaan (Zulkifli, 2007).
Keputusan Menteri Kesehatan Republik Indonesia KEPMENKES No.1076/MenKes/SK/VII/2003 sudah membuat aturan dalam pelaksanaan pengobatan tradisional yang memiliki prinsip, yaitu: (1) tidak berbahaya, tidak melanggar norma dan aturan agama serta keyakinan kepada Tuhan Yang Maha Esa yang telah diakui di Negara Indonesia, (2) aman digunakan dan memiliki manfaat untuk kesehatan, (3) harus berupaya dalam meningkatkan derajat kesehatan masyarakat, (4) harus sesuai dengan nilai dan norma yang berlaku di masyarakat (USU, 2011).

Menteri Kesehatan RI pada acara the $3^{\text {rd }}$ Conference on Traditional Medicine in Asean Countries menyampaikan bahwa obat tradisional bisa dijadikan salah satu bagian yang penting dalam sistem kesehatan di ASEAN dan dunia. Di Indonesia sudah diberlakukan Keputusan Menteri Kesehatan sebagai landasan hukum penggunaan obat tradisional. Keputusan tersebut mempunyai tujuan supaya tersedianya obat tradisional yang berkualitas, berkhasiat, aman, teruji secara ilmiah dan terbukti secara empiris di kalangan masyarakat baik secara individu maupun dalam pelayanan formal.

Masyarakat yang ada diwilayah UPT Puskesmas Batang Tumu mayoritas berpendidikan SD $(72,9 \%)$ sehingga sehingga kurang mengetahui bagaimana mengembangkan obat tradisional untuk menurunkan hipertensi (toga, tanaman obat keluarga), selain itu kondisi geografis yang kurang memungkinkan dan didukung dengan pasang surutnya air sehingga masyarakat jika berbelanja kepasar seminggu sekali atau dua minggu sekali dan 
mereka rata-rata dirumah ada menyimpan persediaan ikan asin yang kaya akan garam yang dapat memicu kenaikan hipertensi bagi siapa saja yang memiliki riwayat hipertensi. Selain itu faktor lain yang menyebabkan masyarakat menyediakan ikan asin dirumah dikarenakan faktor hewan yang mengganggu tanaman sayur-sayuran masyarakat untuk bercocok tanam seperti babi hutan. Masyarakat disana pekerjaan mayoritas petani dalam arti kata kerja kopra atau kelapa, sehingga mereka setelah pulang kerja tidak sempat untuk beraktifitas bercocok tanam dan disana masyarakat mempunyai faktor kebiasaan untuk tidak bercocok tanam sayur-sayuran.

\section{Hubungan sikap lansia dalam penggunaan obat tradisional untuk menurunkan hipertensi}

Hasil penelitian ini menunjukkan bahwa hubungan sikap lansia dengan penggunaan obat tradisional untuk menurunkan hipertensi di UPT Puskesmas Batang Tumu Kabupaten Inhil diperoleh hasil sikap lansia positif 38 responden (64.4\%). Hasil uji statistik dapat disimpulkan nilai $p$ value 0,004. Hasil penelitian ini sesuai dengan penelitian yang dilakukan Desni (2011) dengan hasil $p$ value 0.000 yang berati terdapat korelasi yang signifikan antara sikap kepala keluarga dengan pengambilan keputusan dalam pengobatan tradisional. Desni mengungkapkan bahwa salah satu variabel yang menentukan pengambilan keputusan adalah sikap.Hasil penelitian ini juga sesuai dengan penelitian yang dilakukan oleh (Awaluddin, 2017) bahwa adanya hubungan sikap keluarga dengan tindakan pencegahan demam berdarah dengue dengan nilai probabilitas 0,009 (p value $<0,05)$. Meskipun penelitian tersebut tentang demam berdarah dengue, namun dapat dilihat bahwa sikap seseorang berhubungan dengan tindakan seseorang.

Sikap merupakan salah satu predisposisi yang cukup stabil dalam waktu yang lama dan akan mempengaruhi perilaku seseorang. Definisi lain tentang sikap yaitu suatu kecenderungan seseorang untuk melakukan suatu tindakan, bisa bersikap positif atau negatif. Sikap dipengaruhi oleh beberapa faktor yaitu pengalaman individu, budaya, dan orang lain yang berpengaruh. Sikap terbentuk karena adanya interaksi sosial dengan orang lain dalam waktu yang lama dan berkelanjutan. Sikap dalam menentukan pengobatan juga terjadi dalam waktu yang lama (Walgito, 2010).

Menurut Zulkifli (2007), peminat pengobatan tradisional dipengaruhi oleh beberapa faktor yaitu (a) faktor sosial : masyarakat bisa merawat sendiri dan mendampingi keluargnya dalam pengobatan sehingga hubungan, keakraban dan komunikasi antara anggota keluarga dapat terjalin dengan baik. Meskipun ada juga masyarakat yang lebih memilih pengobatan konvensional dan dirawat di rumah sakit. Kadang-kadang mereka dibawa ke pengobatan tradisional karena alasan biaya. Biaya rumah sakit cenderung lebih tinggi dari pengobatan tradisional. Kemungkinan juga masyarakat belum pernah berobat ke rumah sakit sehingga belum bisa membandingkan biaya antara keduanya. Faktor sosial ini juga dipengaruhi oleh pengalaman masyarakat dalam berinteraksi dengan orang lain; (b) faktor budaya : 
merupakan salah satu alasan masyarakat dalam memilih pengobatan tradisional. Faktor budaya ini memandang bahwa pengobatan tradisonal dapat memberikan kekuatan spiritual sehingga secara psikologis akan membantu proses penyembuhan. Hal ini juga didukung oleh pendapat Foster dan Anderson bahwa pengobatan merupakan bagian integral dari budaya masyarakat. (c) assesibilitas : pengananan yang diterima lebih cepat dan tidak perlu menunggu hasil pemeriksaan penunjang seperti hasil pemeriksaan laboratorium. (d) faktor ekonomi : masyarakat lebih memilih pengobatantradisional karena biayanya yang relatif lebih murah dibandingkan dengan biaya di rumah sakit. Sistem pembayaran juga tidak memerlukan uang pendaftaran dan uang muka serta pembayaran dapat diangsur bagi yang kurang mampu (Zulkifli, 2007).

Sikap juga dipengaruhi oleh beberapa faktor yang membentuk sikap.Menurut Riswandi (2016) sikap dibentuk melalui 4 hal yaitu : (a) keadaan klasik: terjadinya proses belajar karena adanya stimulus yang berlangsung dalam waktu yang lama, sehinggastimulus awal menjadi suatu isyarat bagi stimulusberikutnya. (b). Keadaan instrumental: terjadinya proses belajar karena adanya suatu perilaku yang menyenangkan. Sebaliknya, jika ada perilaku yang tidak menyenangkan maka seseorang akan menghindari perilaku tersebut (c). Belajar melalui observasi: merupakan proses belajar dengan mengobservasi perilaku orang lain dan kemudian meniru perilaku tersebut. Perilaku jenis ini banyak dilakukan oleh seseorang. (d). perbandingan sosial : proses belajar ini dilakukan dengan cara membandingkan perilaku seseorang dengan orang lain untuk memastikan bahwa perilaku yang dibuat seseorang merupakan suatu hal yang benar (Riswandi, 2016).

Implikasi keperawatan dari hasil penelitian ini menunjukan bahwa diperlukan pengetahuan yang baik dan sikap yang positif bagi lansia agar dapat memanfaatkan obat tradisional hipertensi. Obat tradisional hipertensi merupakan salah satu terapi alternatif yang lebih aman bagi lansia.

\section{KESIMPULAN}

Berdasarkan hasil penelitian yang dilakukan dapat disimpulkan bahwa ada hubungan yang signifikan antara tingkat pengetahuan dan sikap lansia dengan penggunaan obat tradisional untuk menurunkan hipertensi di UPT Puskesmas Batang Tumu Kabupaten Inhil dengan uji statistik $p$ value $0,004<$ alpa 0,05. Penelitian ini menunjukan bahwa diperlukan pengetahuan yang baik dan sikap yang positif bagi lansia agar dapat memanfaatkan obat tradisional hipertensi. Diharapkan penelitian selanjutnya tentang perbandingan efek obat tradisional dan konvensional untuk menurunkan hipertensi sehingga dapat dimanfaatkan untuk kemajuan ilmu keperawatan komplementer. 
DAFTAR PUSTAKA

Aoki Y, Yoon S. S., Chong Y., Carrol, M. D. (2014). Hypertension, abnormal cholesterol, and high body mass index among non-hispanic asian adult. United States, 2011-2012. NHCS Data Brief, 140.

Awaluddin. (2017). Korelasi pengetahuan dan sikap keluarga terhadap tindakan pencegahan demam berdarah dengue. 2(October), 263-269. https://doi.org/10.22216/jen.v2i3.2084

Awaluddin, A. Y. Y. (2016). Hubungan pengetahuan dan shalat terhadap tekanan darah pada lansia. Endurance, 1(October), 144-151.

Dinas Kesehatan Provinsi Riau (2015). Profil kesehatan riau. Jurnal Published. Pekanbaru Riau: Http://dinkesriau.net/downlot.php?file=Pro fil $\% 20$ Kesehatan $\% 20$ Provinsi $\% 20$ Riau $\% 2$ 0Tahun\%202015.pdf. Diakses pada tanggal 20 Maret 2017.

Dinas Kesehatan Inhil. (2015). Profil kesehatan kabupaten indragiri hilir. Jurnal Published: Plt Kepala Dinas Kabupaten Indragiri Hilir. http: //www. depkes.go.id /resources/download/pusdatin/profilkesehatan Indonesia-2015. Pdf. Diakses pada tanggal 15 Maret 2017.

Fajri Yenni, (2013). Hubungan pengetahuan dan kepercayaan dengan penggunaan obat pada penderita hipertensi di desa lamnga kecamatan masjid raya kabupaten aceh besar.

Pusat Data Kemenkes RI. (2014). Info datin pusat data dan informasi kementerian kesehatan ri. Pdf Published: Kemenkes RI:
Jakarta

Selatan.

Http://www.balitbangham.go.id/pocontent /peraturan/uu.\%20no\%2023\%20tahun\%20

1992\%20tentang\%20kesehatan.pdf.

Diakses pada tanggal 14 Februari 2017.

Riset Kesehatan Dasar(RISKESDAS). (2013). Badan Penelitian dan Pengembangan Kesehatan Departemen Kesehatan, Republik Indonesia.

Riswandi. (2016). Hubungan pengetahuan dan sikap ibu terhadap penyakit dbd di sidomulyo pekanbaru, pekanbaru.

Sarwono, S.W.,\& Meinarno, E.A. (2009) Psikologi sosial. Jakarata: Salemba Humanika.

Sunaryati, S.S. (2011). 14 penyakit paling sering menyerang dan mematikan. Jogjakarta: Flash Books

USU. (2011). Faktor-faktor pembentuk kepercayaan terhadap pengobatan medis. Jurnal Published: Universitas Sumatera Utara: http:// reposytory.usu.ac.id/ bitstream/1-9/38935/4/chapter\%2011.pdf. Diakses pada tanggal 14 Maret 2017

Walgito, B. (2010). Pengantar psikologi umum. Yogyakarta: Penerbit Andi

Zaenurrohmah, D. H., \& Rachmayanti, R. D. (2017). Hubungan pengetahuan dan riwayat hipertensi dengan tindakan pengendalian tekanan darah pada lansia. Jurnal Berkala Epidemiologi, 5(2), 174-18.

Zulkifli. (2004). Pengobatan tradisional sebagai pengobatan alternatif harus dilestarikan. Jurnal Fakultas Kesehatan Masyarakat, Universitas SumateraUtara. 